\title{
Value chain analysis of total quality control, quality performance and competitive advantage of agricultural SMEs
}

\author{
Abdul Kahara ${ }^{a}$, Muh. Ikbal A. ${ }^{a}$, Tampanga, Rahma Masdar ${ }^{\mathrm{a}}$ and Masrudin ${ }^{\mathrm{a}}$ \\ ${ }^{a}$ Accounting Department, Faculty of Economics \& Business, Tadulako University, Palu, Indonesia \\ A B S T R A C T \\ Article history: \\ Received September 19, 2021 \\ Received in revised format \\ October 24, 2021 \\ Accepted November 172021 \\ Available online \\ November 192021 \\ Keywords: \\ Total quality control \\ Competitive advantage \\ Quality performance
}

Value added activity

Value chain analysis

\section{Introduction}

Cocoa (Theobroma cacao L) is one of the leading commodities in the national plantation sector. Based on data from the Directorate General of Plantations in 2014, Indonesia is in the third position $(651,618$ tons) of the world's largest cocoa producer after Ivory Coast $(1,276,000$ tons) and Ghana $(686,000)$. As much as $22.5 \%$ of Indonesia's cocoa production is produced by Central Sulawesi Province (146,844 tons), as well as being ranked first in cocoa production in Indonesia. Central Sulawesi Province has a strategic position and is highly competitive in producing cocoa products. The phenomenon of the last three cocoa production continues to decline, from 2017 production of 134,320 tons, in 2018 to 125,470 tons, then in 2019 it increased to 127,669 tons (BPS, 2020). Regulations that prohibit the export of commodities in the form of cocoa beans have triggered a decline in production volume in Central Sulawesi. The purpose of the regulation is that cocoa products can be processed to increase product competitiveness. Changing product advantages from the form of raw materials to processed products requires investment to build a processing industry. Organizations are required to be able to adapt to the current situation which is increasingly so that the organization must move to follow the changes that occur. In dealing with these conditions, organizations need a competitive advantage strategy in order to remain in a position in the market. Domingo (2002) stated that to win the competition, companies need to focus on product quality. Furthermore, Hitt et al. (1997) stated that product quality is a company's top priority in creating its competitive advantage. Young \& Selto (1991) describe that a number of companies in the United States respond to global competition by adopting a strategy of establishing superior product quality. The implementation of total quality control by using the dimensions of Total Quality Management (TQM) simultaneously is able to form a competitive advantage Powell (1995). Kurogane (2005) stated that total quality control is the ability of the process to check for defective products in building quality. Quality performance will create organizational competitive advantage, then competitive advantage will shape organizational performance improvement (Alghamdi \& Bach, 2013; Ariyadi, 2021).

* Corresponding author

E-mail address: abdulkahar.untad@gmail.com (A. Kahar)

(C) 2022 Growing Science Ltd. All rights reserved.

doi: $10.5267 /$ j.uscm.2021.11.008 


\section{Literature review}

\subsection{Employee Empowerment, Training and Teamwork on Total Quality Control}

Al-Zoubi et al. (2017) found three components to analyze total quality control, that are empowerment and total employee involvement, continuous training, and a quality-based teamwork culture. The three dimensions of total quality control also have an effect in increasing organizational commitment (Hanaysha, 2016). The findings of previous studies prove that quality management practices based on the concept of total quality management (TQM) influence improving quality performance (Sila, 2007; Terziovski \& Samson, 2000). Other research that uses the concept of total quality control (TQC) which focuses more on the concept of total quality control also proves that total quality control has a contribution in improving organizational quality performance (Lakhal et al., 2006). Control is an activity that is expected to produce changes in organizational culture towards strengthening goal congruence (Kahar et al., 2013). The similarity of goals between organizations and employees is the main orientation of control. Sofjan (2008) defined quality control as an activity to ensure whether policies in terms of quality (standards) can be reflected in the results. In other words, quality control is an effort to maintain the quality or quality of the services produced, so that they are in accordance with the service standards set based on company policies. Al-Zoubi et al. (2017) found three components to analyze total quality control, namely: 1) Empowerment and total employee involvement; 2) Continuous training; 3) build a quality-based teamwork culture. Empirical evidence shows that the implementation of quality management can improve the company's quality performance. This has been measured in various ways and found that the specific quality management models and practices that best predict performance vary across the world (Adam et al., 1997; Prajogo \& Sohal, 2004). The research framework for quality management proposed by Flynn et al. (1994) suggested that the input of this framework is the practice of quality management (QM) whereas quality performance represents the results. Japanese companies formulate total quality control based on competitive advantage (Basu, 2001; Yousuf, 2021). Thus, the competitive advantage strategy is largely determined by the ability of the quality control system to create quality processes and products. Basu (2001) stated the determination of quality standards and design, process planning and design control, management of machinery and equipment. The following is the formulation of the hypothesis that will be tested:

\section{$\mathbf{H}_{1}$ : Employee empowerment influences quality performance. \\ $\mathbf{H}_{2}$ : Employee training affects quality performance. \\ H3: Teamwork culture affects quality performance.}

\subsection{Quality Performance and Competitive Advantage}

Empirical evidence shows that quality management practices, both broadly based on total quality management (TQM), as well as total quality control (TQC) have a narrow contribution to improving organizational performance (Sila, 2007; Lakhal et al., 2006; Terziovski \& Samson, 2000). Dimensions of quality in the manufacturing industry in addition to emphasizing product quality, it is also necessary to pay attention to quality in the production process. Several studies have shown that it is important to prioritize process quality as an indicator of a production process that produces quality products or services. A quality process is a guarantee of a final product that is free from defects and there is no more waste that must be paid dearly by consumers because the product must be discarded or reworked. Quality performance is one of the indicators of organizational performance measurement. Quality performance is built on the dimensions of product design, process flow management, and top management support (Flynn et al., 1995; Riswanto, 2021). The quality performance dimension is used to see from which side the quality is assessed. The dimensions of quality have been described by Gasvertz (2005) for the manufacturing industry. It includes the performance, features, reliability, conformance, durability, serviceability, esthetics and perception. More specifically, the first is performance referring to the suitability of the product with the main function of the product itself or the operating characteristics of a product. Secondly, features refer to product characteristics that distinguish it from other products which are complementary characteristics and are able to create a good impression for customers. Thirdly, reliability refers to namely customer confidence in the product because of its reliability or because of the low probability of damage. Fourth, conformance refers to the suitability of the product with certain requirements or sizes or the extent to which the design and operating characteristics meet the established standards. Fifth, durability refers to the level of product resistance or longevity of the product. Sixth, Serviceability refers to the ease with which the product will be repaired or the ease of obtaining the components of the product. Seventh, aesthetics refers to the beauty or attractiveness of the product. Eighth, perception refers to consumer fanaticism for the brand of a particular product because of the image or reputation of the product itself. Total quality control practices implement cost leadership strategies, develop human resources, increase profitability and meet customer expectations. So, it can be said that quality can be an important way to gain a competitive advantage. The following is the formulation of the hypothesis:

$\mathbf{H}_{4}$ : Quality performance influences the creation of competitive advantage. 
Competitive advantage is the ability of an organization to achieve a market advantage over its competitors. Market advantage can be achieved through cost leadership or through differentiation advantage (Porter, 2008). Li et al. (2006) state that competitive advantage is the ability of an organization to create a defensive position against competitors. These capabilities enable an organization to differentiate itself from its competitors and are the result of critical management decisions (Tracey et al., 1999). The value chain model is a useful analytical tool for defining the organization's core competencies in achieving competitive advantage with a competitive advantage approach. The product value chain is an activity that starts from raw materials to after-sales handling. According to David (2006) the value chain includes activities that occur because of relationships with suppliers (Supplier Linkages), and relationships with consumers (Consumer Linkages). Value Chain analysis helps managers to understand the company's position in the product value chain to increase competitive advantage (Weiler \& Schemel, 2004). Value chain analysis accumulates the total margin of value-added activities and reduces nonvalue added activities. Alghamdi and Bach (2013) stated that when TQM is implemented properly it will be a source of sustainable competitive advantage. Furthermore, Reed et al. (2000) also argue that quality management content is able to create cost leadership advantages and differentiation advantages. Then, it is supported by Elshaer and Augustyn (2016) who find that quality management also has a direct influence on competitive advantage in hotel companies in Egypt. Alghamdi \& Bach (2013) state that to create competitive advantage, it is important for companies to manage quality, both product quality and service quality. Providing high quality products and services will increase satisfaction which in turn creates customer loyalty in the long term.

There are studies that show a strong relationship between product quality performance and increased competitive advantage (Domingo, 2002; Hitt et al., 1997; Al-Zoubi et al. (2017). Thus, organizations must develop a total quality culture through well-designed training. Yusuf \& Kahar (2018) found the importance of strategy formulation in achieving organizational competitive advantage. Research Al-Zoubi et al. (2017) stated that organizations should concentrate on advancing production technology and improving product quality, which is important to improve performance and create competitiveness. Alghamdi \& Bach (2013) state that to create competitive advantage, it is important for companies to manage quality, both product quality and service quality. Whatever strategy is chosen, value chain analysis will help the company to focus on the chosen strategic plan and strive to gain competitive advantage. The following can be formulated research hypotheses:

H5: The relationship between employee empowerment and competitive advantage is mediated by quality performance.

H6: The relationship between employee training and competitive advantage is mediated by quality performance.

$\mathbf{H}_{7}$ : The relationship between teamwork culture and competitive advantage is mediated by quality performance.

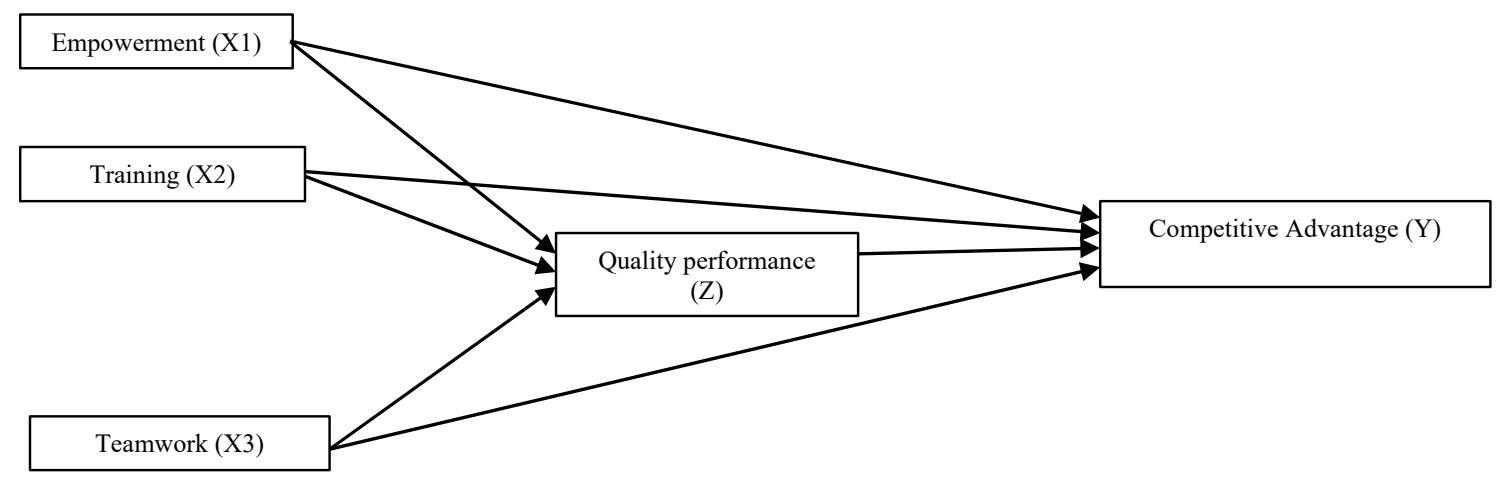

\section{Research method}

Fig. 1. Research Model

This research is a verification research that aims to verify research questions related to competitive advantage. The research model was formulated to test the research hypothesis. The research hypothesis stated that quality performance is influenced by the antecedent variables of total quality control and its consequences for the creation of competitive advantage. This research is expected to provide input that supports decision making about the relative value of two or more alternative actions (Sugiyono, 2014). Data collection using survey method. In addition to conducting interviews with cocoa SMEs, researchers also had the opportunity to see and participate in some of the activities carried out by farmers in cocoa plantations. Primary data was obtained from distributing questionnaires and interviews to cocoa SMEs in Central Sulawesi Province. Total quality control in this study has sub-variables, namely: employee empowerment, measured by 5 questionnaire items, employee training measured by 5 questionnaire items and teamwork culture measured by 6 questionnaire items, all of which were developed from the indicators used by Hanaysha (2016). Quality performance used 6 indicators of the 8 indicators developed by Gasvertz (2005), with the consideration that serviceable and perception indicators cannot be measured in cocoa SMEs. 
Quality performance indicators are made into 9 statement items. The measurement of competitive advantage refers to the five indicators proposed by Zhang \& Lado (2001) and later developed by Li et al. (2006) which consist of; indicators of price/cost, quality, delivery dependability, product innovation, and time to market. The indicator is then developed into 8 statement items. The population of this research is cocoa SMEs in Central Sulawesi Province. Parigi Moutong, Sigi and Palu as cocoa centers were selected as the research object with the total population being 243 SMEs. The number of samples is 83 respondents with an allowance of $10 \%$. The sample was selected based on the random sampling method. The data analysis technique used in this research is statistical inferences. In addition to conducting validity and reliability analysis to test the reliability of research instruments, data analysis was also carried out by applying the multiple regression method in stages for path analysis. Testing the significance of the structural model using the Sobel formula.

\section{Results}

\subsection{Respondent Characteristics}

The description of respondents who returned the questionnaire as many as 83 SMEs can be categorized according to the amount of turnover produced. SMEs with a turnover of cocoa production per month under 2 tons as many as 24 SMEs or $30 \%$. A total of 40 SMEs or $48 \%$ with a turnover of between 2 and 5 tons per month, 13 SMEs or $16 \%$ of cocoa SMEs with a turnover of between 5 and 10 tons, and 6 businesses or $7 \%$ with a turnover of more than 10 tons per month. This proportion shows that the majority of respondents are traders with a turnover of 2 tons to 5 tons per month, this shows that SMEs still have the potential to increase their business scale up to 5 to 10 tons per month. SMEs operating cocoa for under 1 year are 7 SMEs or $9 \%$, businesses that have been running for 1 to 5 years are 10 SMEs or $12 \%$, SMEs that have been in business for between 5 years to 10 years are 46 SMEs or 55\%, and 20 SMEs or $24 \%$ who have been in business for more than 10 years. The description of cocoa SMEs from the perspective of their business segments is categorized into cocoa SMEs that specialize in processing cocoa, SME businesses that process cocoa and other agricultural products, and cocoa SMEs that are multibusiness. The description of the three categories, only 13 SMEs or $16 \%$ whose business focus is only in the field of cocoa processing, there are 47 SMEs or $56 \%$ which are SMEs collecting agricultural products including cocoa, and as many as 23 or $28 \%$ of cocoa SMEs are multi-business businesses. This data shows that SMEs that focus on cocoa business are still low, and more SMEs are combining their business with other agricultural commodities, even by doing multi-business. This certainly has an effect on the quality control and performance of the cocoa produced.

\subsection{Descriptive Statistics of Variables}

Cocoa SMEs empirically consider that the delegation of authority to subordinates is the most important factor in empowerment with a response in the very high category (average 4.32). Overall, the empowerment variable in the context of total quality control was responded to in the high category (average 4.09), which illustrates that cocoa SMEs in Palu City consider that employee empowerment can increase the effectiveness of quality control. Moreover, employee training as one of the dimensions of quality control in the cocoa SME business in Palu City is empirically considered to be successful if the training is in accordance with what is being carried out. The suitability of the task in the training was responded to in the very high category (average 4.32). Overall, the training variables responded to the same as the dimensions of empowerment in the high category (average 4.13). In addition, the teamwork culture in this study was measured by 6 indicators. Cocoa SMEs consider that a teamwork culture will be effective if there is empathy between fellow team members, in this study the response was in the very high category (average 4.4). Meanwhile, in general the teamwork culture was also responded to in the high category (average 3.9). In terms of quality performance, it is measured by 8 item statements. Cocoa SMEs responded empirically that the accuracy of measurement plays a very important role in creating quality performance (average 4.26). In reality, cocoa production has many quality standards, so the measurement of quality standards in these businesses is a very decisive aspect. In general, the quality performance variable was responded to in the high category (average 3.7). Lastly, regarding competitive advantage, cocoa SMEs in creating competitive advantage consider that the factor of meeting standards is a very important aspect (average 4.32). In general, cocoa SMEs interpret competitive advantage in the high category (average 3.8). The description between the quality performance variable and competitive advantage has high consistency, where the aspect of excellence in measuring quality performance is responded to the highest because it is the main factor in meeting standards which is also the highest response to the competitive advantage variable.

\subsection{Hypothesis testing}

Total quality control in research was developed more specifically to examine the effects of individual dimensions. Simultaneous testing as shown in Table 1 shows the probability of sig F change $0.000(<0.05)$ means that simultaneously employee empowerment, employee training and teamwork culture have a significant effect on quality performance in cocoa SMEs. The coefficient of determination (R) as measured by Adjusted R square shows the result of 0.562 . Thus, it can be concluded that $56.2 \%$ of the relationship between quality performance and total quality control can be explained. 
Table 1

Model Summary of Quality Performance

\begin{tabular}{|c|c|c|c|c|c|}
\hline \multirow{2}{*}{$\mathrm{R}$} & \multirow{2}{*}{ R Square } & \multirow{2}{*}{ Adjusted R Square } & \multirow{2}{*}{ Std. Error of the Estimate } & \multicolumn{2}{|c|}{ F- Statistics } \\
\hline & & & & $\mathrm{F}$ & Sig. F \\
\hline $.760^{\mathrm{a}}$ & .578 & .562 & 2.81263 & 36.070 & .000 \\
\hline
\end{tabular}

a. Predictors:(Constant), cooperation, training, empowerment

Table 2

Coefficients of Quality Performance Antecedents

\begin{tabular}{|c|c|c|c|c|c|}
\hline Model & $\mathrm{B}$ & Std. Error & Beta (Standardized) & $\mathrm{t}$ & Sig. \\
\hline (Constant) & 6.128 & 2.898 & & 2.115 & .038 \\
\hline Empowerment & .378 & .178 & .228 & 2.129 & .036 \\
\hline Training & .385 & .184 & .222 & 2.088 & .040 \\
\hline Cooperation & .655 & .161 & .414 & 4.070 & .000 \\
\hline
\end{tabular}

dependent variable: Quality_Performance

Table 2 shows the partial regression coefficients of the total quality control variables on quality performance. The regression coefficient of the employee empowerment variable is 0.228 with a significant probability of $0.036(<0.05)$, the regression coefficient of the employee training variable is 0.222 , which is significant at $0.040(<0.05)$ and the regression coefficient of the teamwork culture variable is 0.414 significant at 0.000 . $(<0.05)$. Moreover, the coefficient of determination $(\mathrm{R})$ of the competitive advantage consequence model with an Adjusted R Square value of 0.731 (Table 3).

Table 3

Model Summary of Competitive Advantage

\begin{tabular}{|c|c|c|c|c|c|}
\hline \multirow[b]{2}{*}{$\mathrm{R}$} & \multirow[b]{2}{*}{ R Square } & \multirow[b]{2}{*}{ Adjusted R Square } & \multirow[b]{2}{*}{ Std. Error of the Estimate } & \multicolumn{2}{|c|}{ Change Statistics } \\
\hline & & & & F Change & Sig. F \\
\hline $.863^{\mathrm{a}}$ & .744 & .731 & 1.90468 & 56.723 & .000 \\
\hline
\end{tabular}

Predictors:(Constant), Quality_Performance, Cooperation, Training, Empowerment

Table 3 shows that the formulation of the research model is able to explain $73.1 \%$ of the relationship between antecedent variables, intervening variables and consequence variables. The significance of the research model is also valid with a sig $\mathrm{F}$ change probability of $0.000(<0.05)$.

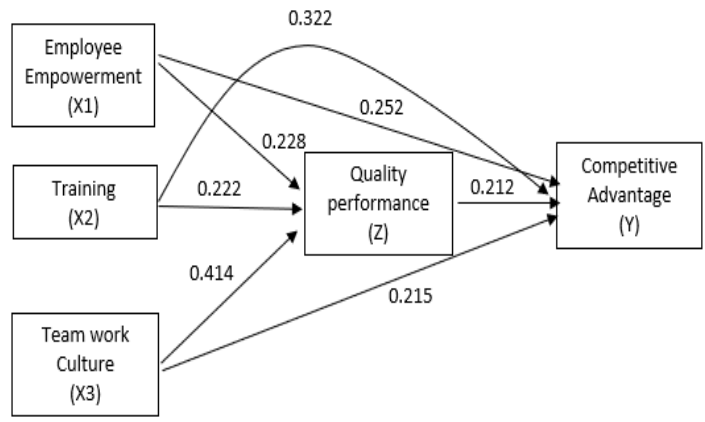

Fig. 2. Structural Pathway Model

Table 4

Coefficients of Competitive Advantages Antecedents

\begin{tabular}{|c|c|c|c|c|c|}
\hline Model & B & Std. Error & Beta (Standardized) & $\mathrm{t}$ & Sig. \\
\hline (Constant) & .971 & 2.017 & & .481 & .632 \\
\hline Empowerment & .361 & .124 & .252 & 2.917 & .005 \\
\hline Training & .483 & .128 & .322 & 3.762 & .000 \\
\hline Cooperation & .294 & .120 & .215 & 2.450 & .017 \\
\hline Performance & .184 & .076 & .212 & 2.409 & .018 \\
\hline
\end{tabular}

dependent variable: Competitive Advantages 
The consequence model in this study uses path analysis to examine the total effect magnitude of the total quality control antecedent variable on the consequence variable of competitive advantage, through quality performance. The results also showed the direct effect of employee empowerment on competitive advantage shows a path coefficient of 0.252 which is significant at $0.005(<0.05)$. The indirect effect through quality performance is $0.0484(0.228 \times 0.212)$ so that the total effect is 0.299 . In addition, the direct effect of employee training on competitive advantage shows a path coefficient of 0.322 which is significant at $0.000(<0.05)$. Meanwhile, the indirect effect through quality performance is $0.047(0.221 \times 0.212)$ so that the total effect is 0.369 . The direct effect of teamwork culture on competitive advantage shows a path coefficient of 0.215 which is significant at $0.017(>0.05)$. The indirect effect through quality performance is $0.087(0.414 \times 0.212)$ so that the total effect is 0.303 .

The significance of the test results of the path analysis model can be tested using the Sobel test. The effect of employee empowerment on competitive advantage through quality performance is significant, where t count is 1.703 which is greater than $t$ table (1.677). The effect of employee training on competitive advantage through quality performance has a Sobel test $t$ value of 1.786 which is greater than $t$ table (1.677) which is concluded to be significant. The effect of teamwork culture on competitive advantage through quality performance has the results of the Sobel test $t$ count of 1.750 which is greater than the $\mathrm{t}$ table (1.677) which is concluded to be significant (Figure 2).

\subsection{Discussion}

The results highlight the antecedents of total quality control on quality performance. The formulation of the competitive advantage consequence model has proven to have model validity so that it can be stated that total quality control has a significant effect on competitive advantage through improving quality performance. The test results show that total quality control through employee empowerment, training and a culture of teamwork mediated quality performance contributes significantly to the competitive advantage of cocoa SMEs in Palu City. Empirical data shows that cocoa SMEs respond highly to the delegation of authority on employee empowerment. The suitability of the training material with daily tasks is an indicator of the success of the training. The attitude of tolerance/empathy among employees in completing tasks together will form a strong teamwork culture. Employee empowerment in this study has a significant effect on improving quality performance. A strong factor in shaping employee empowerment is the delegation of authority. Cocoa SMEs in Palu City interpret that when management gives broad authority to employees to make decisions related to their duties, the achievement of quality performance will be more effective. According to Faustino (1995), employee training is every effort to improve the performance of workers in a particular job that is their responsibility. This statement is in line with the results of research where employee training with indicators in the perspective of total quality control has a significant effect on improving quality performance. A more comprehensive description of the training process according to Reid et al. (1995) is the concept of planned training. Planned training is a careful intervention designed to produce the insights needed to improve job performance. Robbins et al. (2012) stated that work teams or work groups compared to individual efforts resulted in higher performance. This has the understanding that the performance achieved by a team is higher than the performance of individuals in an organization or a company. This statement supports the results of research that found a significant effect of teamwork culture in the perspective of total quality control on quality performance. Teamwork that forms a culture within an organization will be more effective in achieving organizational goals, both financial and non-financial. According to David (2006), teamwork is a group of people to work together to achieve the same goal and that goal will be easily obtained by working in a team rather than doing it alone.

The results also showed the consequences of competitive advantage. This is in line with Al-Zoubi et al. (2017) stating that to develop quality management and to improve the implementation of total quality control effectively. The results of this study are in line with research that uses the dimensions of total quality management (TQM), oriented more broadly in improving quality performance (Adam et al., 1997; Prajogo \& Sohal, 2004). Kurogane (2005) stated that quality control builds process quality in detecting defective products in building product quality. Thus, total quality control will ensure that the quality policy will be achieved through value added activities in the form of high-quality performance. (Sofjan, 2008). Process quality is a manifestation of total quality control practices. Total quality control is in line with value chain analysis which accumulates value-added activities and reduces non-value-added activities (Weiler \& Schemel, 2004). The consequence of implementing total quality control that influences improving quality performance is the creation of a competitive advantage for cocoa SMEs in Palu City. Cocoa product quality performance will be achieved if SMEs can prioritize decentralized delegation of authority in empowering employees, conducting training according to employee duties and functions, and cultivating tolerance and empathy in working together. The results are in line with the research of Reed et al. (2000) which stated that quality management content is able to create competitive advantage and Elshaer and Augustyn (2016) who find that quality management also has a direct influence on competitive advantage. Companies must create quality processes through total quality control to create competitive advantage. Providing quality products will increase customer satisfaction which in turn creates long-term loyalty (Alghamdi \& Bach, 2013). 


\section{Conclusion}

The study presented the results regarding antecedent model of total quality control which has been developed into employee empowerment, employee training and a culture of teamwork has a positive contribution in improving product quality performance in cocoa SMEs. The consequence of implementing total quality control will improve the quality performance of cocoa products, which in the end will create a competitive advantage that is more inclined to differentiation advantage, namely technical/method superiority and human resources who are able to carry out measurement activities accurately and quickly. Empirically, the quality of cocoa products is dominantly determined by the accuracy of measurement. Cocoa production activities are full of measurements both in-process and post-processing. The standard components of cocoa product quality consist of the quantity of cocoa beans with the size of the number of beans per ounce, the number of deflated beans, moistureless, mold content, etc. Each standard component has a different measurement technique/method, so special specification skills are needed for employees to carry out precise measurements. One of the obstacles faced in increasing the competitive advantage of cocoa products in Central Sulawesi is the inefficiency of the production process, low quality and long distribution channels. This indicates that it is necessary to identify value-added cocoa production activities in order to reduce quality costs, which will create a competitive advantage for products to improve quality performance. This study is considered useful in identifying total quality control activities that have added value at the cocoa SMEs. Managerially, total quality control is expected to improve product quality performance which in turn will form a competitive advantage. Ultimately, the competitive advantage of cocoa SMEs will form a value chain of distribution channels that will support the industrialization of cocoa products in Central Sulawesi.

\section{References}

Adam, J. M. (1997). Unités rédactionnelles et genres discursifs: cadre général pour une approche de la presse écrite. Pratiques, 94(1), 3-18.

Alghamdi, H., \& Bach, C. (2013). Quality as competitive advantage. International Journal of Management \& Information Technology, 8(1), 1265-1272.

Al-Zoubi, A. A. K., Al-Nassar, B. A. Y., \& Alzu'bi, F. A. (2017). The Role of Total Quality Control (TQC) in the Technical. Journal of Social Sciences (COES\&RJ-JSS), 6(3), 656-665.

Ariyadi, W. (2021). Empirical Analysis of Farmers Household Food Security Levels in Salatiga, Indonesia. Research Horizon, 1(1), 39-46.

Badan Pusat Statistik (BPS). (2020). Statistik Kakao Indonesia 2019 (Indonesian Cocoa Statistics 2019). Jakarta: BPS. Retrieved from https://www.bps.go.id/publication/2020/12/02/2ac5a729f43e5f6b666e482d/statistik-kakao-indonesia2019.html.

Basu, R. (2001). Six sigma to fit sigma. IIE solutions, 33(7), 28-28.

David, F. R. (2006). Manajemen strategis (Edisi 10). Jakarta: Salemba Empat.

Domingo, R. T. (2002). Global competitiveness through total quality. Retrieved February, 7, 2010.

Elshaer, I. A., \& Augustyn, M. M. (2016). Direct effects of quality management on competitive advantage. International Journal of Quality \& Reliability Management, 33(9), 1286-1310.

Flynn, L. R., Goldsmith, R. E., \& Eastman, J. K. (1994). The King and Summers opinion leadership scale: Revision and refinement. Journal of Business Research, 31(1), 55-64.

Gaspersz, V. (2005). Sistem Manajemen Kinerja Terintegrasi: Balanced Scorecard dengan Six Sigma Untuk Organisasi Bisnis dan Pemerintah.

Gomes Faustino, C. (1995). Manajemen Sumber Daya Manusia. Yogyakarta: BPFE.

Hanaysha, J. (2016). Examining the effects of employee empowerment, teamwork, and employee training on organizational commitment. Procedia-Social and Behavioral Sciences, 229, 298-306.

Hitt, M. A., Ireland, R. D., \& Hoskisson, R. E. (1997). Manajemen Strategis: Menyongsong Era Persaingan Bebas dan Globalisasi (Terj. Armand Hediyanto). Jakarta: Erlangga.

Kahar, A., Triyuwono, I., Irianto, G., \& Ludigdo, U. (2013). Management control systems concept construction of "pangngadereng" based on local wisdom values. Journal of Business and Management, 8(2), 21-30.

Kurogane, K. (2005). Hinshitsukanrinyumon (Introduction to Quality Control). Tokyo: Japan Standards Association.

Lakhal, L., Pasin, F., \& Limam, M. (2006). Quality management practices and their impact on performance. International Journal of Quality \& Reliability Management.

Li, S., Ragu-Nathan, B., Ragu-Nathan, T. S., \& Rao, S. S. (2006). The impact of supply chain management practices on competitive advantage and organizational performance. Omega, 34(2), 107-124.]

Porter, M. E. (2008). Competitive advantage: Creating and sustaining superior performance. New York: Simon and Schuster.

Powell, T. C. (1995). Total quality management as competitive advantage: a review and empirical study. Strategic management journal, 16(1), 15-37.

Prajogo, D. I., \& Sohal, A. S. (2004). Transitioning from total quality management to total innovation management: an Australian case. International journal of quality \& reliability management. 
Reed, R., Lemak, D. J., \& Mero, N. P. (2000). Total quality management and sustainable competitive advantage. Journal of Quality Management, 5(1), 5-26.

Reid, D. G., Krebs, C. J., \& Kenney, A. (1995). Limitation of collared lemming population growth at low densities by predation mortality. Oikos, 387-398.

Riswanto, A. (2021). Competitive Intensity, Innovation Capability and Dynamic Marketing Capabilities. Research Horizon, $1(1), 7-15$.

Robbins, M., Greene-Schloesser, D., Peiffer, A. M., Shaw, E., Chan, M. D., \& Wheeler, K. T. (2012). Radiation-induced brain injury: a review. Frontiers in oncology, 2, 73.

Sila, I. (2007). Examining the effects of contextual factors on TQM and performance through the lens of organizational theories: An empirical study. Journal of Operations management, 25(1), 83-109.

Sofjan, A. (2008). Manajemen Produksi dan operasi. Jakarta: Lembaga Penerbit Fakultas Ekonomi Universitas Indonesia.

Sugiyono. (2014). Metode Penelitian Kuantitatif, Kualitatif, dan Kombinasi (Mixed Methods), Bandung: Alfabeta.

Terziovski, M., \& Samson, D. (2000). The effect of company size on the relationship between TQM strategy and organisational performance. The TQM magazine.

Tracey, M., Vonderembse, M. A., \& Lim, J. S. (1999). Manufacturing technology and strategy formulation: keys to enhancing competitiveness and improving performance. Journal of operations management, 17(4), 411-428.

Weiler, J., \& Schemel, N. (2004). Value Chain And Value Coalitions, ICH White paper.

Young, S. M., \& Selto, F. H. (1991). New manufacturing practices and cost management: A review of the literature and directions for research. Journal of Accounting Literature, 10(1991), 265-298.

Yousuf, M. (2021). Challenges and opportunities of artificial insemination on dairy cattle in Ethiopia. Research Horizon, $1(2)$.

Yusuf, M., \& Kahar, A. (2018), Strategy Formulation Model to Improve Implementation of Corporate Social Responsibility (CSR). International Journal of Civil Engineering and Technology (IJCIET), 9(11), 243-256.

Zhang, M. J., \& Lado, A. A. (2001). Information systems and competitive advantage: a competency-based view. Technovation, 21(3), 147-156.

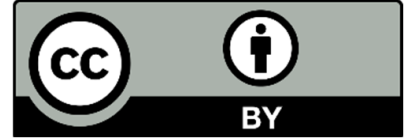

(C) 2022 by the authors; licensee Growing Science, Canada. This is an open access article distributed under the terms and conditions of the Creative Commons Attribution (CCBY) license (http://creativecommons.org/licenses/by/4.0/). 